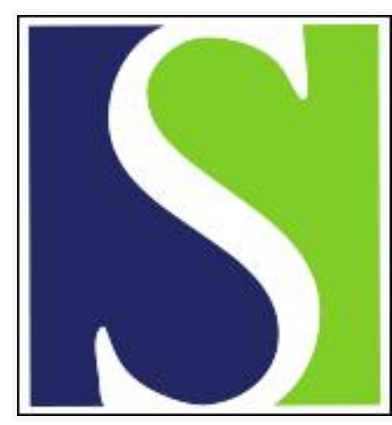

Scand J Work Environ Health 1996;22(2):108-111

https://doi.org/10.5271/sjweh.118

Issue date: Apr 1996

\title{
Malignant melanoma among lithographers
}

by Nielsen $\mathrm{H}$, Henriksen L, Olsen JH

\section{Corrections}

See SJWEH Supplements 2008;(4):0-0 for a correction.

The following articles refer to this text: 1997;23(4):308;

2011;37(5):359-362

Key terms: cancer risk; hydroquinone

This article in PubMed: www.ncbi.nlm.nih.gov/pubmed/8738888 


\title{
Malignant melanoma among lithographers
}

\author{
by Henrik Nielsen, MD, ${ }^{1}$ Leif Henriksen, MD, ${ }^{2}$ Jørgen H Olsen, $M D^{3}$
}

\begin{abstract}
Nielsen $\mathrm{H}$, Henriksen L, OIsen $\mathrm{JH}$. Malignant melanoma among lithographers. Scand $\mathrm{J}$ Work Environ Health $1996 ; 22: 108-11$.
\end{abstract}

\begin{abstract}
Objectives Mortality studies have suggested that workers in the printing industry may have a higher incidence of malignant melanoma. The aim of this study was to assess the incidence of malignant melanoma among lithographers.

Methods A cohort of 837 lithographers, born in 1933-1942, was followed in the Danish Cancer Register from 1974 to 1989.

Results Five cases of malignant melanoma were found, with 1.5 expected (relative risk $3.4,95 \%$ confidence interval $1.2-7.5$ ).

Conclusions Many known and suspected carcinogens are used in the printing industry. Hydroquinone, used for photographic development, may be implicated in the observed increase in risk, as it causes depigmentation and changes in melanocytes in the skin.
\end{abstract}

Key terms cancer risk, hydroquinone.

Occupational mortality studies have shown an increased incidence of malignant melanoma in the printing industry or in the printing trades. Dubrow (1) estimated a combined relative risk of 1.98 for this malignancy (based on 23 cases) from nine earlier studies. This finding was surprisingly not confirmed in two large record-linkage studies of occupational cancer in Denmark. The first study analyzed the employment histories of 94000 cancer patients diagnosed in 1970-1979 (2); the second linked the 1970 census population to the files of the Danish Cancer Registry for the period 1970-1980, comprising 115000 cancers (3).

The present study of cancer risk was based on a cohort of 837 lithographers who started work in the trade between 1947 and 1977. The cohort was established initially to investigate risk for brain damage from exposure to organic solvents. [Those results have been given elsewhere (4).] The group was studied carefully to detect exposures to chemicals used during the study period.

\section{Subjects and methods}

Danish lithographers are mainly skilled workers, and more than $90 \%$ belong to the Danish Union of Lithogra- phers. The study group thus comprised 837 lithographers, born between 1933 and 1942 (median 51 years, 1989) and registered in the files of the Danish Union of Lithographers as of 1 April 1974 or later. Members who left the Union after that date were retained in the files; one person who could not be traced was excluded from further study. Information on date of emigration or death was obtained from the files of the Danish Central Population Register.

The remaining 836 lithographers were linked to the files of the Danish Cancer Registry, which began reporting incidence data in 1943. The period of follow-up for cancer occurrence was taken from 1 April 1974, or the date of first membership in the Union for those becoming a member later, to the date of death, or 31 December 1989. The total number of cancers registered among the cohort members was recorded for each site. Tumors were classified according to a modified version of the International Classification of Diseases, seventh revision. National incidence rates by gender and five-year age and calendar-year groups for these tumor categories were applied to the appropriate person-years under observation to obtain the number of cancers expected, had the cohort members experienced the same rates of cancer incidences that prevailed in the general population of Denmark. The statistical methods used were based on

1 Occupational Health Service, BST Storkøbenhavn A/S, Copenhagen, Denmark.

2 Department of Neurosurgery, Glostrup Hospital, Copenhagen, Denmark.

3 Danish Cancer Society, Division for Cancer Epidemiology, Copenhagen, Denmark.

Reprint requests to: Dr Henrik Nielsen, Aabakkevej 8, DK-2720 Vanløse, Denmark. 
the assumption that the observed number of cancer cases in any specific category follows the Poisson distribution. Tests of significance and 95\% confidence intervals (95\% CI) were calculated for the relative risk (RR), taken as the ratio of the observed-to-expected cancers.

Information on type of work, use of chemicals, and extent of exposure for the cohort members was obtained from a questionnaire mailed in June 1989. Seven questionnaires were not delivered because of a change of address, 32 cohort members were dead, and two had emigrated. The questionnaire was returned by 631 of the 795 persons who received it (a response rate of $79 \%$ ), and 620 contained enough information to be used in the study.

\section{Exposures}

All of the subjects had worked in the printing industry, beginning with exposure to chemicals between 1947 and 1977 ; $98 \%$ of the group had begun work in the trade before 1965 . Skilled workers comprised $90 \%$ of the study group and had served a full four- to five-year apprenticeship immediately after leaving school. The group had worked steadily within the trade. At the time of the investigation, $96 \%$ were active in the labor market $(88 \%$ employed, $5 \%$ unemployed, $4 \%$ sick), and the remaining $4 \%$ had a disability pension. About half the group worked as offset printers (some were retrained typographers) and the other half in other jobs (eg, reprophotographers, copyists and photoengravers). About 200 lithographers had worked regularly by hand with photographic chemicals and were exposed to hydroquinone.

The subjects' reports indicated that they had been exposed to organic solvents for a mean of 26 years, had used a mean of 261 of organic solvents per week during cleaning, and had washed plates or machinery for a mean of 32 times a week. Organic solvents mentioned in the questionnaire (number of persons in parentheses) was benzine (489), spirit (379), paraffin (356), turpentine (336), and toluene (307). Other commonly used chemicals mentioned were pigments, dyes, acids, photochemicals, hydroquinone, chromates, and cyanides. More than 2000 products are used in the Danish printing industry (5).

Lithographers have much less exposure to organic solvents and chemicals today than they did earlier. According to the questionnaires, $46 \%$ now have no exposure to these compounds in their daily work, and $53 \%$ of the workshops have local exhaust ventilation, compared with $5 \%$ in the 1950 s. Exposure to organic solvents has been markedly reduced because of the use of computer technology and vegetable oils and changes in technical and chemical processes. Film development has been an automatic encapsulated process for a long time, although a variety of chemicals is still used (6).
Table 1. Cancers among 836 lithographers born in 1933-1942 and followed in 1974-1989. ( $0=$ number of observed cancers, $\mathrm{E}=$ number of expected cancers, $95 \% \mathrm{Cl}=95 \%$ confidence intervals)

\begin{tabular}{|c|c|c|c|c|}
\hline Site & 0 & $\mathrm{E}$ & O/E & $95 \% \mathrm{Cl}$ \\
\hline Buccal cavity and pharynx (140-148) & - & 1.37 & & \\
\hline Stomach $(151)$ & 1 & 0.92 & 1.1 & $0.1-5.4$ \\
\hline Colon (153) & - & 1.41 & & \\
\hline Rectum (154) & 2 & 1.04 & 1.9 & $0.3-6.4$ \\
\hline Liver (155) & - & 0.20 & & \\
\hline Larynx (161) & 1 & 0.54 & 1.8 & $0.1-9.0$ \\
\hline Lung (162) & 3 & 3.31 & 0.91 & $0.2-2.5$ \\
\hline Testis (178) & & 1.76 & & \\
\hline Kidney $(180)$ & - & 0.93 & & \\
\hline Bladder (181) & 1 & 1.70 & 0.59 & $0.0-2.9$ \\
\hline Malignant melanoma (190) & 5 & 1.49 & 3.4 & $1.2-7.5$ \\
\hline Other skin (191) & 5 & 4.39 & 1.1 & $0.4-2.5$ \\
\hline Brain (193) & 2 & 1.56 & 1.3 & $0.2-4.2$ \\
\hline Bone $(196)$ & 1 & 0.09 & 11.4 & $0.6-56$ \\
\hline Malignant lymphoma (200-202) & 2 & 1.31 & 1.5 & $0.3-5.0$ \\
\hline Leukemias (204) & & 0.72 & & \\
\hline Other and unspecified & 1 & 3.44 & 0.29 & $0.0-1.4$ \\
\hline All cancers $(140-205)$ & 24 & 26.18 & 0.92 & $0.6-1.4$ \\
\hline
\end{tabular}

a Code of the International Classification of Diseases, seventh revision, in parentheses.

\section{Results}

A total of 24 cancer cases was observed with 26.2 expected, yielding a nonsignificant decreased relative risk of 0.92 for cancer (table 1 ).

Five cases of malignant melanoma were identified within the study period, while 1.5 were expected (RR $3.4,95 \%$ CI 1.2-7.5); and five cases of nonmelanocytic skin cancer were seen, with 4.4 cases expected (RR 1.1, nonsignificant).

Table 2 gives details for the five cases of malignant melanoma, four of the patients having responded to the questionnaire. The latency from the first exposure as an apprentice to the time of diagnosis was at least 22 years. Two were employed as offset printers and two as photoengravers exposed to hydroquinone. The last patient had worked as a reprocopyist, but we have no information on exposure. They were all alive in 1989, and working in the trade, except patient number 1 , who was on a disability pension.

\section{Discussion}

The follow-up of this small group of lithographers, aged 47 to 56 years, appears to confirm the earlier findings of an increased risk for malignant melanoma in the printing industry. The lithographers were skilled workers and long-term members of the same union. In all five cases occupational exposure had begun early in the study period. Selection bias, due to exclusion of workers who left the trade before 1974 because of exposure, was as- 
Table 2. Five cases of malignant melanoma among lithographers.

\begin{tabular}{|c|c|c|c|c|c|}
\hline \multirow[t]{2}{*}{ Patient $^{a}$} & \multirow{2}{*}{$\begin{array}{l}\text { Year } \\
\text { of } \\
\text { birth }\end{array}$} & \multirow{2}{*}{$\begin{array}{l}\text { Year of } \\
\text { first } \\
\text { exposure }\end{array}$} & \multirow{2}{*}{$\begin{array}{l}\text { Occupation and } \\
\text { exposures }\end{array}$} & \multicolumn{2}{|c|}{ Malignant melanoma } \\
\hline & & & & $\begin{array}{l}\text { Year of } \\
\text { diagnosis }\end{array}$ & Origin and type \\
\hline 1 & 1933 & 1948 & Photoengraver: organic solvents, photochemicals & 1984 & $\begin{array}{l}\text { Trunk, } \\
\text { Superficial spreading }\end{array}$ \\
\hline 2 & 1933 & 1948 & Photoengraver: organic solvents, photochemicals & 1988 & $\begin{array}{l}\text { Trunk, } \\
\text { Not otherwise specified }\end{array}$ \\
\hline 3 & 1935 & 1951 & $\begin{array}{l}\text { Lithographic printer: organic solvents, } \\
\text { pigments, dyes }\end{array}$ & 1983 & $\begin{array}{l}\text { Trunk, } \\
\text { Nodular }\end{array}$ \\
\hline 4 & 1938 & 1957 & Lithographic printer: organic solvents, pigments, dyes & 1979 & $\begin{array}{l}\text { Trunk, } \\
\text { Superficial spreading }\end{array}$ \\
\hline 5 & 1939 & unknown & $\begin{array}{l}\text { Reprocopyist: usual exposure (organic solvents, } \\
\text { pigments, dyes, photochemicals) }\end{array}$ & 1986 & $\begin{array}{l}\text { Head or neck, } \\
\text { Not otherwise specified }\end{array}$ \\
\hline
\end{tabular}

a All but number 5 answered the questionnaire. Information on the trade for no 5 was obtained from the union.

sumed to be small but in any case would have tended to underestimate the risk. The overall cancer risk was as expected. Altogether, 10 cancers of the skin were observed.

Danish, English, and Swedish surveillance studies $(2,3,7,8)$ have reported no increased risk for malignant melanoma in the printing industry or related trades. The industrial categories used in the studies may, however, have been too broad, resulting in an attenuation of the measured risk associated with work as a lithographer. In the printing industry in Sweden, an elevated risk of melanoma was found among printers (typographers), journalists, and editors (9).

We were unable to distinguish between the carcinogenic effects of the exposure to pigments, dyes, and organic solvents. We wish, however, to draw attention to hydroquinone, in view of its biological effect on melanocytes. Hydroquinone has been used in bleaching creams and resulted in temporary depigmenting, followed by ochronosis, colloid milium and damage to the melanocytes (10). It is presumed that hydroquinone interferes with the production of dopamine from dihydroxyphenylalanine (levodopa) and tyrosine. It is therefore interesting that the administration of levodopa to patients with Parkinson's disease results in a relatively rapid recurrence of melanomas diagnosed and treated previously (11). Depigmentation of the skin has also been observed in photographers after the use of hydroquinone (12). Two of the five cases in our study had been exposed to hydroquinone since 1948, one for 8 and the other for 25 years. Thereafter, films were developed by hand, the result being hours of dermal exposure. After the mid1960s and early 1970s, developing machines were used.

A high incidence among professional occupations in the printing industry may point to a life-style rather than to an occupational hazard (9). Increased risks for malignant melanoma have been observed in the pharmaceutical industry (13), in association with exposure to polychlorated biphenyls (14), vinyl chloride monomer (15) and soldering (16). Undoubtedly the risk for developing melanoma is multifactorial, sun exposure probably being the most important factor (17). Chemical compounds in combination with sun exposure may increase the risk for malignant melanoma among lithographers.

\section{References}

1. Dubrow R. Malignant melanoma in the printing industry. Am J Int Med 1986;10:119—26.

2. Olsen $\mathbf{J H}$, Jensen MD. Occupation and risk of cancer in Denmark. Scand J Work Environ Health 1987;13 suppl 1:35 p.

3. Lynge E, Thygesen L. Occupational cancer in Denmark. Scand J Work Environ Health 1990;16 suppl 2:91 p.

4. Henriksen L, Nielsen H, Arlien-Söborg P, Laraignou P, Videbæk H. Organiske opløsningsmidlers indvirkning på hjernens funktion og struktur hos litografer [The effect of organic solvents on brain function and structure in lithographers]. Copenhagen: Arbejdsmiljøfondet, 1992.

5. Seedorff L, Boserup B, Gundestrup M. Stoffer og materialer i grafiske virksomheder [Products and materials in printing shops]. Copenhagen: Arbejdsmiljøfondet, 1981.

6. Seedorff L, Frederiksen H. Fotokemikalier: arbejdsmiljørisici og løsningsmuligheder [Photographic processing: chemical hazards and their prevention]. Copenhagen: Arbejdsmiljøfondet, 1991.

7. Vågerö D, Swerdlow AS, Beral V. Occupation and malignant melanoma: a study based on cancer registration data in England and Wales and in Sweden. Br J Ind Med 1990;47:31724.

8. Malker HSR, Gemne G. A register-epidemiological study on cancer among Swedish printing industry workers. Arch Environ Health 1987:42:73-82.

9. McLaughlin JK, Malker HSR, Blot WJ, Ericsson JLE, Gemne G, Fraumeni JF. Malignant melanoma in the printing industry. Am J Ind Med 1988;13:301 4 .

10. Findlay GH, Morrison JGL, Simson IW. Exogenous ochronosis and pigmented colloid milium from hydroquinone bleaching creams. Br J Dermatol 1975;93:613-23.

11. Fermaglich J, Delaney P. Parkinson's disease, melanoma and levodopa. J Neurol 1977;215:221-4.

12. Fisher AA. Hydroquinone use and abnormal reactions. Cutis 1983;31:240-50. 
13. Thomas TL, Decouflé P. Mortality among workers employed in the pharmaceutical industry: a preliminary investigation. $\mathrm{J}$ Occup Med 1979;21:619-23.

14. Heldaas SS, Andersen SS, Langård S. Incidence of cancer among vinyl chloride and polyvinylchloride workers: further evidence for an association with malignant melanoma. Br J Ind Med 1987;44:278 - 80.

15. Bahn AK, Rozerwaike I, Herrmann N, Grover P, Stellmann J, O'Leary K. Melanoma after exposure to PCB's. N Engl J Med 1976;295:451.
16. Vågerö D, Ahlbom A, Olin R, Sahlsten S. Cancer morbidity among workers in the telecommunication industry. Br J Ind Med 1985;42:191-5.

17. Østerlind A, Tucker MA, Stone BJ, Jensen OM. The Danish case-control study of cutaneous malignant melanoma: II. importance of UV-light exposure. Int J Cancer 1988;42:31924 .

Received for publication: 27 March 1995 